\title{
Protective Effect of Combination Commercial Black Seed Oil (Nigella sativa) and Honey Against Cisplatin-Induced Hepatotoxicity in Rats
}

\author{
Andri Muhrim Siddiq ${ }^{1}$, Muhammad In'am Ilmiawan², Mitra Handini ${ }^{3}$ \\ 1) Medical Education Program, Faculty of Medicine, Tanjungpura University, Pontianak \\ 2) Departement of Biology and Pathobiology, Medical Education Program, Faculty of Medicine, Tanjungpura University, \\ Pontianak \\ 3) Departement of Medical Physiology, Medical Education Program, Faculty of Medicine, Tanjungpura University, Pontianak \\ *Corresponding author: andrimuhrimsiddiq@gmail.com
}

\begin{abstract}
Background: The chemotherapeutic use of cisplatin (CP) is restricted because of its hepatotoxicity induced by oxidative stress. Malondialdehyde (MDA) is a secondary product of lipid peroxidation as a biomarker of oxidative stress. Individual administration of black seed oil (BSO) or honey $(\mathrm{H})$ demonstrated hepatoprotective effect in rats. Interaction of both substances when administrated as combination can be evaluated using combination index $(\mathrm{CI})$ to quantitatively depict synergism $(\mathrm{CI}<1)$, additive $(\mathrm{CI}=1)$ and antagonism effect $(\mathrm{CI}>1)$. Purposes: to know the combination effect of BSO and honey on rat liver tissue given $\mathrm{CP}$ exposure. Methods: This study used 30 rats were divided into 10 groups. Normal group (N); Negative control group (NC); P1-P4 groups were administrated BSO (1 and $2 \mathrm{~mL} / \mathrm{kg}$ ) and honey (3.7 and $7.4 \mathrm{~mL} / \mathrm{kg}$ ); P5-P8 groups were combination of BSO and $\mathrm{H}$. P1-P8 groups were given $\mathrm{BSO}$ and honey orally for 21 days. On the $18^{\text {th }}$ day, NC and P1-P8 groups were given CP $8 \mathrm{mg} / \mathrm{kg}$ intraperitoneally, while the $\mathrm{N}$ group was given $\mathrm{NaCl} 0.9 \% 1 \mathrm{~mL} / \mathrm{kg}$ intraperitoneally. Result: Malondialdehyde (MDA) levels were found to be lower in P1-P8 groups compared to negative control group and P6 and P7 groups have levels equivalent to MDA levels of normal control group ( $p>0.05$ ). Conclusion: Combination of BSO and honey provides a protective effect on cisplatin-induced rat liver tissue damage indicated by reduced MDA levels, but all combination group showed antagonism effect.
\end{abstract}

Keywords: Black Seed Oil, Honey, Cisplatin, Malondialdehyde, Combination Index.

\section{INTRODUCTION}

Cisplatin (CP) is a potent chemotherapeutic agent utilized for several types of cancers such as ovary, cervical, testicular, nasopharyngeal and lung cancer (1). Although CP is a potent chemotherapeutic agent, its usage is limited by its hepatotoxicity effect. CP induced hepatocellular injuries such as sinusoidal dilatation, venular fibrosis and centrilobular vein injury (2). CP-induced toxicity is reported to be mediated by an increase in reactive oxygen species (ROS) (3). ROS could interrupt antioxidant defense mechanism and lead to extensive tissue damage and cell dysfunction by reacting with macromolecules such as proteins, membrane lipids and nucleic acids (4). Reaction of ROS with unsaturated lipids produces a wide variety of oxydation 
products such as lipid hydroperoxides (LOOH), malondialdehyde (MDA), propanal, hexanal and 4-hydroxynonenal (4-HNE). MDA is an end product of decomposition by arachidonic acid and polyunsaturated fatty acids (PUFAs) through the enzymatic of nonenzimatic process (5).

Dietary substances with antioxidant activity have been used in recent years. Plants such as Nigella sativa (NS) and honey $(\mathrm{H})$ provide dietary sources of biologically active components that exhibit wide spectrum of biological properties such as antioxidant, anti-inflammatory and hepatoprotective. NS is one of the herbal medicines that has been extensively observed and obtained worldwide acknowledgment. Thymoquinone and polyunsaturated fatty acids (PUFA) are two important elements in NS that could suppress oxidative stress level and repairing cell membranes (6). Honey $(\mathrm{H})$ is a natural product widely used both as food and medicine. Natural honey contains many flavonoids, phenolic acids, ascorbic acid, tocopherol, catalase, superoxide dismutase, glutathione and peptides (7). Most of the compounds above cooperated and provide a synergic antioxidant effect (8). Thus, the potential clinical use of $\mathrm{CP}$ and numerous health benefits of NS and honey, this study aimed to determine the protective effect of NS and honey combination on CP-induced rat liver tissue damage.

\section{METHODS}

This study was an experimental study with randomized post test only control group design conducted in nonmicroscopic laboratory, Faculty of Medicine, Tanjungpura University, Pontianak in October 2018-Februari 2019. This study is a continuation from previous research that discussed about protective effect of the combination of BSO and $\mathrm{H}$ that using liver (9), and in this study using the same livers as previous research.

Animal protocol: Thirty male Wistar rats (Rattus norvegicus) weighing 180-220 g (23 months old) were acclimatized for one week and received ad libitum diet. The rats were divided into 10 groups. Normal group (N); Negative control group (NC); P1 group was given $\mathrm{BSO}$ dose $1(1 \mathrm{~mL} / \mathrm{kg}) ; \mathrm{P} 2$ group was given $\mathrm{BSO}$ dose $2(2 \mathrm{~mL} / \mathrm{kg})$; $\mathrm{P} 3$ group was given $\mathrm{H}$ dose $1(3.7 \mathrm{~mL} / \mathrm{kg}) ; \mathrm{P} 4$ group was given $\mathrm{H}$ dose $2(7.4 \mathrm{~mL} / \mathrm{kg})$; $\mathrm{P} 5$ group was given $\mathrm{BSO}$ dose 1 and $\mathrm{H}$ dose 1 (1 $\mathrm{mL} / \mathrm{kg}$ and $3.7 \mathrm{~mL} / \mathrm{kg}$ ); P6 group was given BSO dose 1 and $\mathrm{H}$ dose $2(1 \mathrm{~mL} / \mathrm{kg}$ and 7.4 $\mathrm{mL} / \mathrm{kg}$ ); $\mathrm{P} 7$ group was given BSO dose 2 and $\mathrm{H}$ dose $1(2 \mathrm{~mL} / \mathrm{kg}$ and $3.7 \mathrm{~mL} / \mathrm{kg}) ; \mathrm{P} 8$ group was given $\mathrm{BSO}$ dose 2 and $\mathrm{H}$ dose 2 ( $2 \mathrm{~mL} / \mathrm{kg}$ and $\mathrm{H} 7.4 \mathrm{~mL} / \mathrm{kg}$ ). P1-P8 groups were given $\mathrm{BSO}$ and honey orally for 21 days. On the $18^{\text {th }}$ day, NC and P1-P8 groups were given CP $8 \mathrm{mg} / \mathrm{kg}$ intraperitoneally, while the $\mathrm{N}$ group was given $\mathrm{NaCl} 0.9 \% 1$ $\mathrm{mL} / \mathrm{kg}$ intraperitoneally.

MDA measurement: MDA levels were determined by Will's method.(10) Tetramethoxypropane (TMP) was used as an external standard reagent which is diluted to $0 ; 0.3125 ; 0.625 ; 1.25 ; 2.5 ; 5 ; 10$ $\mathrm{nmol} / \mathrm{mL}$ and expressed as nmol of MDA. The reaction mixture contained $300 \mu \mathrm{L}$ of $1 \%$ TBA in $50 \%$ glacial acetic acid. All solutions were then heated at $95-100^{\circ} \mathrm{C}$ for 10 minutes. After the sample was cooled, the sample absorbance measured at $532 \mathrm{~nm}$ with spectrophotometer. The standard curve equation obtained is $\mathrm{y}=0,1043 \mathrm{x}+$ 0,0166 (" $x$ " is MDA concentration and " $y$ " is absorbance of standard solution) with correlation coefficient $\left(\mathrm{R}^{2}\right)=0.9775$. 
Statistical and combination index analysis: Statistical analyzed using SPSS ver. 23 (IBM Corporation, Armonk, NY) for windows and conducted by KruskalWallis followed by Mann-Whitney. A probability level of $\mathrm{p}<0.05$ was selected as indicator of statistical significance. Combination index (CI) analysed by Compusyn. CI interpreted as follows: (11)
a. $\mathrm{CI}<1$ : very strong synergism
b. CI 0.1-0.3 : strong synergism
c. CI 0.3-0.7 : synergism
d. CI 0.7-0.85 : moderate synergism
e. CI 0.85-0.90 : slight synergism
f. CI $0.90-1.10$ : nearly additive
g. CI 1.10-1.20 : slight antagonism
h. CI 1.20-1.45 : moderate antagonism
i. CI 1.45-3.3 : antagonism
j. CI 3.3-10 : strong antagonism
k. CI > 10 : very strong antagonism.

All animal in the experiment were conducted according to the institutional guidelines and were approved by the Ethics Committee of Tanjungpura University (No.3558/UN22.9/DL/2018).

\section{RESULT}

\section{Effect of administration CP, BSO, $\mathrm{H}$, and} combined BSO and $H$ on MDA levels.

Hepatotoxicity induced by $\mathrm{CP}$ was characterized by significantly increasing in MDA levels in NC group compared to the $\mathrm{N}$ and P1-P8 groups. BSO or honey groups demonstrated significant reduction of MDA levels induced by CP. MDA levels in combination groups (P5-P8) have lower MDA levels than a single treatment groups (P1-P4). There was no significant difference between P6 and P7 groups to the $\mathrm{N}$ group. MDA levels of liver tissue induced by $\mathrm{CP}$ can be seen in table 1 and figure 1 .
Table 1. Mean and standard deviation (SD) of liver MDA Levels in CP-induced

\begin{tabular}{lc}
\hline \multicolumn{1}{c}{ Groups } & MDA (nmol/mL) $+\mathrm{SD}$ \\
\hline $\mathrm{N}$ & $1.46 \pm 0.13$ \\
$\mathrm{NC}$ & $2.7 \pm 0.005$ \\
$\mathrm{BSO} 1$ (P1) & $1.87 \pm 0.15$ \\
$\mathrm{BSO}$ (P2) & $2.17 \pm 0.28$ \\
$\mathrm{H} 1$ (P3) & $2.36 \pm 0.06$ \\
$\mathrm{H} 2$ (P4) & $1.87 \pm 0.14$ \\
$\mathrm{BSO} 1-\mathrm{H} 1$ (P5) & $1.85 \pm 0.07$ \\
$\mathrm{BSO} 1-\mathrm{H} 2(\mathrm{P} 6)$ & $1.55 \pm 0.03$ \\
$\mathrm{BSO} 2-\mathrm{H} 1$ (P7) & $1.47 \pm 0.21$ \\
$\mathrm{BSO} 2-\mathrm{H} 2$ (P8) & $2.02 \pm 0.14$ \\
\hline
\end{tabular}

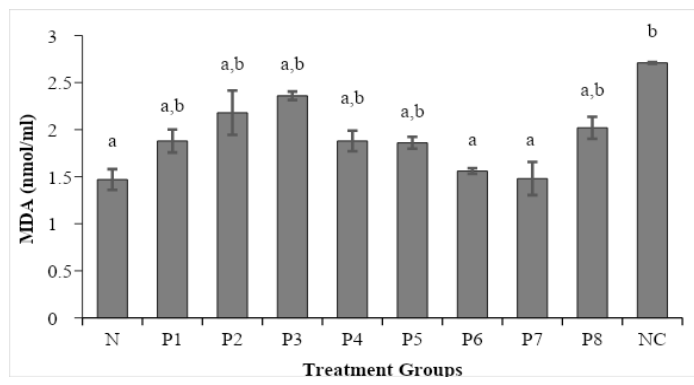

Figure 1. Diagram of liver tissue MDA level. Kruskal Wallis $(\mathrm{p} \leq 0,05)$. $\mathrm{a}=$ significantly from the NC group ( $\mathrm{p} \leq$ $0,05) ; \mathrm{b}=$ significantly from group $\mathrm{N}(\mathrm{p}$ $\leq 0,05)$.

\section{Combination index of NSO and $\mathrm{H}$.}

$\mathrm{CI}$ value of all NSO and $\mathrm{H}$ combination dose treatment groups exhibited antagonism effect. BSO1-H1, BSO10H2, and $\mathrm{BSO} 2-\mathrm{H} 2$-treated group exhibited antagonism while BSO1-H2-administrated group exhibited strong antagonism. CI can be seen in table 2 .

Table 2. Combination Index

\begin{tabular}{clll}
\hline \multirow{2}{*}{ CI } & & \multicolumn{2}{l}{ Honey $(\mathrm{mL} / \mathrm{kg})$} \\
\cline { 3 - 4 } & & 3,7 & 7,4 \\
\hline Black seed & 1 & 1,5 & 2,6 \\
oil $(\mathrm{mL} / \mathrm{kg})$ & 2 & 4,5 & 2,6 \\
\hline
\end{tabular}

\section{DISCUSSION}

During normal physiologic events, ROS are continuously produced and removed by antioxidant defence mechanisms. In 
pathological conditions, excessive production of ROS are results in lipid peroxidation. MDA has been widely used for many years as a biomarker for lipid peroxidation (12). The present study finds MDA levels significantly higher in the NC group compared to treatment groups. This results is in agreement with previous study (13). Where oxidative stress had been implicated in the pathogenesis of CPInduced hepatotoxicity by enhancing ROS generation through up-regulation of NADPH oxidase genes and reduction activities of an enzymatic antioxidant. This study indicates that the treatment groups prevents CP-Induced hepatotoxicity.

In this study, CP increased the production of lipid peroxides but decrease by treatment. The most emphasized property of BSO was the antioxidant effect. Administration of BSO alone shows protective effect on rat liver tissue from damage induced by $\mathrm{CP}$, this occurs due to antioxidant activity such as thymoquinone (TQ). The antioxidant effect of TQ has been investigated against several ROS-inducing agents such as cisplatin (14), doxorobucin (15) and methotrexate (16). Thymoquinone produces significant antioxidant effects, reduces free radicals and increases the activity of liver enzymes, such as superoxide dismutase (SOD). Thymoquinone increases both enzymatic and non enzymatic antioxidants, eliminates free radicals and inhibits mitochondrial dysfunction. Besides TQ, PUFA in BSO also plays role in speeding up repair and regeneration of damaged membranes by replacing PUFA components that have been oxidized by ROS (17).

The protective effect of honey was assessed using a rat model of CP-Induced hepatotoxicity. Previous study also showed the protective effect of honey against CP-
Induced hepatic and renal toxicity through the inhibition of NF-kB-mediated COX-2 expression and induction of oxidative stress-dependent $\quad \mathrm{BAX} / \mathrm{Bcl} 2 /$ caspase-3 apoptotic pathway (18). Antioxidant properties of honey results in decreased ROS levels indicated by decreased MDA levels. These results are in agreement with previous study where honey reduced MDA levels on blood plasma induced by alloxan (19). The antioxidant effects of honey are mainly mediated by phenolic and flavonoid contents (20). Honey inhibits cell membranes oxidation thus prevents cell damage. Flavonoid is one of the polyphenol compounds that can inhibit oxidative reactions by donating one electron to unpaired electrons thus decrease the free radical levels (21).

Combination of BSO and honey showed better effect compared to single administration. Sarina Mohamad et al (22) reported that fat-soluble antioxidant contained in BSO combined with antioxidant available in honey increased antioxidant capacity 3-4 times higher than single administration. The variability of lipid-soluble antioxidant component in BSO and honey mixture may have directly modulated lipid profiles. Lipid-soluble antioxidant compounds have been reported to neutralize free radicals cell membranes by inhibiting lipid peroxidation (23). P7 demonstrated the best protective effect indicated by lowest MDA level with the smallest volume administrated. Nevertheless, Combination index measurement showed all of the treatment group have antagonism effect. The term antagonism is used when the effect of a combination less effective than the sum of the individual effects. While, the term of synergism is used when the addition of agent apparently increases the effect of the 
other, so that the effect of a combination appears to be greater than would be expected. Without synergism and antagonism, the two individual effect are additive.

\section{CONCLUSION}

Oxidative stress has been implicated in the pathogenesis of cisplatin induced hepatotoxicity by enhancing ROS generation indicated by increased MDA levels. The present study confirmed that the administration of $\mathrm{BSO}$ and $\mathrm{H}$ individually or in combination can protect from cisplatin induced hepatotoxicity, but all combination group showed antagonism effect.

\section{ACKNOWLEDGMENT}

The authors gratefully acknowledge Sumo Lestari, ST, Nurhidayati, A. Md, and Amdalia Sri Swastiastuti for their technical help in conducting this research.

\section{CONFLICT OF INTEREST}

Authors state have no conflict of interest, and no affiliation or connection to or with any entity or organization, which may raise a question of bias in discussion and conclusion of the manuscript.

\section{REFERENCE}

1. Gold JM RA. Cisplatin (Cisplatinum). Treasure Island (FL): StatPearls; 2019.

2. Bano N, Najam R. Histopathological and biochemical assessment of liver damage in albino Wistar rats treated with cytotoxic platinum compounds in combination with 5-fluorouracil. Arch Med Sci. 2019;15(4):1092103.

3. Poluektova LY, Arnold LL, Kabanov A V, Cohen SM, Bronich TK. Cisplatin-loaded core cross- linked micelles : comparative pharmacokinetics, antitumor activity, and toxicity in mice. Intern J Nanomed. 2012;7:2557-71.

4. Desai SD, Saheb SH, Das KK, Haseena S. Effect of Thymoquinone on MDA and SOD levels in Sterptozotocine Induced Diabetic Albino Rats . J Pharm Sci Res. 2015;7(8):523-6.

5. Ayala A, Muñoz MF, Argüelles S. Lipid peroxidation: Production, metabolism, and signaling mechanisms of malondialdehyde and 4-hydroxy-2-nonenal. Oxid Med Cell Longev. 2014;2014:1-31.

6. Forouzanfar F, Fazly Bazzaz BS, Hosseinzadeh H. Black cumin (Nigella sativa) and its constituent (thymoquinone): A review on antimicrobial effects. Iran J Basic Med Sci. 2014;17(12):929-38.

7. Miguel MG, Antunes MD, Faleiro ML. Honey as a complementary medicine. Integr Med Insights. 2017;12:1-15.

8. Abdallah MA, Zayed MA, Kelany ME. Antioxidant and antiapoptic effects of combined sidr honey and nigella sativa oil against paracetamol-induced hepatonephrotoxicity in rats. ZUMJ. 2016;22(1):1-12.

9. Alkadri SLF, Ilmiawan MI, Handini M. Efek Protektif Kombinasi Minyak Jintan Hitam dan Madu terhadap Hepatotoksisitas pada Tikus Akibat Sisplatin (The Protective Effects of The Combination of Black Cumin Oil and Honey against Hepatotoxicity in Rats Due Sisplatin). eJKI. 2019;7(2):101-8.

10. Wills ED. Mechanisms of Lipid Peroxide Formation in Animal 
Tissues. Biochem J. 1966;99:66776.

11. Chou TC. Drug combination studies and their synergy quantification using the chou-talalay method. Cancer Res. 2010;70(2):440-6.

12. Ansarin K, Khoubnasabjafari M, Jouyban A. Reliability of malondialdehyde as a biomarker of oxidative stress in psychological disorders. BioImpacts. 2015;5(3):123-7.

13. Palipoch S, Punsawad C, Koomhin P, Suwannalert P. Hepatoprotective effect of curcumin and alphatocopherol against cisplatin-induced oxidative stress. BMC Complement Altern Med. 2014;14(1):1-8.

14. Üstün R, Kaval E, Korkaya H. Thymoquinone prevents cisplatin neurotoxicity in primary DRG neurons. 2018;69:68-76.

15. Mahmoud YK, Abdelrazek HMA. Biomedicine \& Pharmacotherapy Cancer: Thymoquinone antioxidant / pro-oxidant e ff ect as potential anticancer remedy. 2019;115(2019):1-14.

16. Sheikhbahaei F, Khazaei M, Rabzia A, Mansouri K, Ghanbari A. Protective Effects of Thymoquinone against Methotrexate-Induced Germ Cell Apoptosis in Male Mice. Int J Fertil Steril. 2016;9(4):541-7.

17. Farooqui Z, Ahmed F, Rizwan S, Shahid F, Khan A, Khan F. Protective effect of Nigella sativa oil on cisplatin induced nephrotoxicity and oxidative damage in rat kidney. Biomed Pharmacother. 2017;85:715.

18. Neamatallah TA, Nagla AE, Aymn TA, Soad SA BG. Honey protects against cisplatin-induced hepatic and renal toxicity through inhibition of NF-kB-mediated COX-2 expression and oxidative stress dependent BAX/Bcl-2/caspase-3 apoptotic pathway. Food Funct. 2018;1-33.

19. Bela Risqiyani Fajrilah. Pengaruh Pemberian Madu Terhadap Kadar Malondialdehyde (MDA) Plasma Darah pada Tikus Putih Galur Wistar yang Diinduksi Alloxan (The Effect of Honey on The Levels of Malondialdehyde (MDA) Blood Plasma in White Rats Strain Wistar Induced Alloxan). Sains Med. 2013;5(2):98-100.

20. Al-Farsi M, Al-Amri A, AlHadhrami A, Al-Belushi S. Color, flavonoids, phenolics and antioxidant of Omani honey. Heliyon. 2018;4.

21. Cianciosi D, Hernandes TYF, Afrin S, Gasparrini M, Rodriguez PR, Manna PP, et al. Phenolic compounds in honey and their associated health benefits: A review. Molecules. 2018;23:1-20.

22. Mohamad S, Ibrahim N, Yusof H. Blood Pressure and Lipid Lowering Effects of Nigella sativa Seeds and Honey Mixture. IOSR J Nurs Heal Sci. 2014;3(5):89-96.

23. Gupta VK, Sharma SK. Plants as natural antioxidants. Nat Prod Radiance. 2006;5(4):326-34. 